\title{
Institutional roles and the implementation of Local Economic Development, Kasese District, Uganda
}

\begin{tabular}{|c|c|}
\hline $\begin{array}{l}\text { Authors: } \\
\text { Giles Kahika }{ }^{1} \\
\text { Gerald K. Kary }\end{array}$ & $e^{2 j a} a^{2,3}$ \\
\hline $\begin{array}{l}\text { Affiliations: } \\
{ }^{1} \text { Rwenzori Afri } \\
\text { Development } \\
\text { Uganda }\end{array}$ & $\begin{array}{l}\text { ca } \\
\text { Foundation, }\end{array}$ \\
\hline $\begin{array}{l}{ }^{2} \text { Department } \\
\text { Administration } \\
\text { Management, } \\
\text { Management } \\
\text { Uganda }\end{array}$ & $\begin{array}{l}\text { f Public } \\
\text { and } \\
\text { Uganda } \\
\text { Institute, }\end{array}$ \\
\hline $\begin{array}{l}{ }^{3} \text { Department } \\
\text { Administratior } \\
\text { Management, } \\
\text { University, Sol }\end{array}$ & $\begin{array}{l}\text { f Public } \\
\text { and } \\
\text { North-West } \\
\text { th Africa }\end{array}$ \\
\hline $\begin{array}{l}\text { Correspondin } \\
\text { Giles Kahika, } \\
\text { kahikagiles@y }\end{array}$ & $\begin{array}{l}\text { guthor: } \\
\text { ahoo.com }\end{array}$ \\
\hline $\begin{array}{l}\text { Dates: } \\
\text { Received: } 28 \mathrm{~F} \\
\text { Accepted: } 23 \\
\text { Published: } 31\end{array}$ & $\begin{array}{l}\text { eb. } 2017 \\
\text { Mar. } 2017 \\
\text { July } 2017\end{array}$ \\
\hline $\begin{array}{l}\text { How to cite th } \\
\text { Kahika, G. \& K } \\
2017, \text { 'Institut } \\
\text { the implemen } \\
\text { Economic Dev } \\
\text { Kasese District } \\
\text { Africa's Public } \\
\text { Delivery and P } \\
\text { Review 5(1), a } \\
\text { doi.org/10.41 } \\
\text { v5i1.159 }\end{array}$ & $\begin{array}{l}\text { is article: } \\
\text { aryeija, G.K., } \\
\text { onal roles and } \\
\text { tation of Local } \\
\text { elopment, } \\
\text {, Uganda', } \\
\text { Service } \\
\text { erformance } \\
\text { 159. https:// } \\
\text { 2/apsdpr. }\end{array}$ \\
\hline $\begin{array}{l}\text { Copyright: } \\
\text { (C) 2017. The A } \\
\text { Licensee: AOS } \\
\text { is licensed unc } \\
\text { Creative Comr } \\
\text { Attribution Lic }\end{array}$ & $\begin{array}{l}\text { uthors. } \\
\text { S. This work } \\
\text { ler the } \\
\text { nons } \\
\text { ense. }\end{array}$ \\
\hline Read online: & \\
\hline 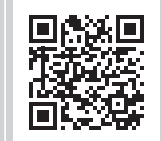 & $\begin{array}{l}\text { Scan this QR } \\
\text { code with your } \\
\text { smart phone or } \\
\text { mobile device } \\
\text { to read online. }\end{array}$ \\
\hline
\end{tabular}

The study examined the relationship between institutional roles and the implementation of Local Economic Development (LED) in Uganda, taking Kasese District as a case study. The study objectives were to examine how technical roles, political roles, Civil Society Organisations and private sector roles affect implementation of LED implementation in Kasese District Local Government. The study was a correlational research design that adopted both quantitative and qualitative approaches. A sample of 120 respondents were observed using questionnaires and interviews. Data were analysed using Pearson correlation coefficient and regressions analysis. The study findings revealed that there is a positive significant relationship between technical roles, political roles, civil society roles and private sector roles with the implementation of LED. The study recommended among others, that local governments should be assisted to create efficacious LED institutions and create LED implementation planning frameworks involving key actors and stakeholders at locality level.

\section{Introduction}

Local Economic Development (LED) as a development strategy has in the recent past gained widespread popularity and acceptance as a grass-root-based approach, especially in the developing world. LED is seen as an empowering strategy with the overall goal of empowering the grass-root people so that they are able to initiate and propel their local socioeconomic prosperity through the promotion of self-reliance (Ministry of Agriculture, Animal Industry and Fisheries, MAAIF, 2012). This study examined how the roles of various actors at the local level affect the implementation of LED in Uganda, with specific focus on Kasese District Local Government. The study investigated the effect of institutional roles in implementing LED in Uganda, taking the case of Kasese District. Specifically, it investigated the following objectives: (1) to examine how technical roles affect LED implementation in Kasese District Local Government, (2) to find out how political roles affect LED implementation in Kasese District Local Government and (3) to explore the effects of the roles of Civil Society Organisations (CSOs) on LED implementation in Kasese District Local Government.

\section{Background}

\section{Historical perspectives}

Local Economic Development has been evolving as a development strategy, the world over, for a number of decades. The period from the 1960s to the early 1980s witnessed economic decline in many developed nations of Europe. During the said period, many of these countries experienced de-industrialisation and capital flight, which, coupled with the effects of globalisation, gave rise to the adoption and use of LED as a development strategy to assist in the regeneration of many local areas and cause development. During the same period, there was a marked shift in development thinking, in which local governments were no longer perceived as merely places of local administrations, but of local entrepreneurialism (Harvey 1989).

From the 1970s onwards, the governments of the United States and the United Kingdom began focusing on the local geographical areas as the centres of growth and development (Harvey 1989). Accordingly, for example, there was a change in the policy in the United States, so that the Federal Government considered it her role to address the economic underdevelopment of the rural areas of American states. During the same period, a more structured strategy of LED emerged in the United Kingdom as a response to the neoliberal economic policies of centralised planning (Harvey 1989).

Under such a situation, several local authorities embarked on a strategy of local economic policymaking giving rise to the establishment of Enterprise Boards (Lawless, 1990; Lawless \& 
Ramsden 1990). These Enterprise Boards were under the stewardship of democratically elected officials and their functionality boosted the lobbying capacity of the local governments thereby compelling the United Kingdom to provide incentives to those subnational units. This, as a consequence, set the ground for LED in the United Kingdom.

Suffice to emphasise that the current global LED evolution started a few decades ago. Generally, three waves of LED evolution have been registered with the first from the 1960s to the early 1980s (Rogerson 2003). During this first LED evolution phase, local governments were using the locality approach to attract external investment and creating an enabling environment to attract business. On the other hand, during the second wave of LED evolution, which ran between the 1980s and 1990s, local governments were more focused on internal development. They realised the importance of being self-sustaining, and so they started to develop and retain businesses as part of creating a local industrial base. Finally, we are currently experiencing the third and current wave of LED evolution (World Bank 2000). This is the wave that began in the late 1990s, and it is during this phase of LED evolution that it is being strengthened by the creation of partnerships, developing the required human resource and the mobilisation of the private financial resources in the form of credit and capital for entrepreneurial development. With that as part of the global background to LED evolution, we move to the African continental scene.

Looking at the history of Africa, the colonial legacy hindered the economic development of many parts of Africa for many years. In most cases, especially in sub-Saharan Africa, postcolonial economic policies worsened the cases of many of those countries. Neocolonialism continued to disrupt the processes aimed at reducing poverty and bringing development to those countries. For quite some time, the African continent remained underdeveloped providing a growing share of the world's absolute poor (Nkurayija 2011). In order to reverse this state of Africa's underdevelopment, several initiatives have been attempted, notably the Lagos Plan of Action 1980, the 1986-1990 Priority Programme of Economic Redressing of Africa adopted by the Organisation of Africa Unity (OAU) in 1985 and the New Partnership for African Development (NEPAD) (Nkurayija 2011).

Alongside these and other development initiatives, we eventually come to a realisation that the top-down approach, which hitherto was the approach to implementing development programmes, was not yielding the desired results. This realisation inevitably precipitated the need for a more efficacious approach to development. Therefore, in the decade beginning the 1990s, LED as an approach was introduced in a number of sub-Saharan African countries as a bottom-up approach. This is expected to ignite economic growth and development through the exploitation of endogenous resources and involving local actors. During this period, LED has become the most attractive and influential policy that was promoted and popularised in many of the countries in west, east and southern Africa (Harvey 1989).

Among the most successful countries in LED implementation is the Republic of South Africa. The promotion of LED in South Africa can be traced in the apartheid era where cities pursued a limited degree of LED largely in the form of place making (Rogerson 1999b in Nel 2001). However, with the fall of apartheid, the involvement of the South African local governments in LED activities had increased as a result of several legislations compelling them to get involved. Currently, South Africa's local government's role in promoting and implementing LED is guaranteed by the 1996 Constitution, the 1998 White Paper on the local government and the Local Government Municipal Systems Act of 2000.

Having made reference to the global development agenda and the local development focus as far as the African continent is concerned, this historical background now takes a glimpse at the background of LED implementation in Uganda.

Uganda adopted the decentralisation system of governance immediately after the National Resistance Movement (NRM) came to power in the mid-1980s. The policy of decentralisation devolved significant political and administrative powers to the local governments. With the promulgation of the 1995 Constitution and the enactment of the Local Government Act of 1997, all elements of decentralised governance were incorporated in Uganda's legal framework. It must be emphasised here that the decentralisation policy was introduced in Uganda's governance system with the overall goal of empowering citizens to take charge of their own development in order to improve their livelihood (Bitarabeho 2008). It should also be stated that, with decentralisation, citizen participation in governance would strengthen service delivery and this would buttress the development process for poverty alleviation and hence development. However with time, this expectation was not realised. That is, even though full-service delivery was available at the local level with citizen participation, the poverty levels remained high and no visible development was in sight. This led to a policy shift in the implementation of the decentralisation system of governance to address the gap in the original design of the decentralisation policy (Mutabwire 2012). The said policy shift brought on board full-scale implementation of LED as an additional objective of the decentralisation policy aimed at enhancing development at the local level.

Uganda adopted a LED policy with an intention to further deepen the decentralisation process, eradicate poverty and ensure inclusive, sustainable and equitable economic growth and development at the locality level (Byabashaija, Novembrieta, Nakimuli, Matovu, \& Manuel, n.d.; Mwesige 2012). According to Uganda's LED policy, LED supports the country's strategy of implementing private sector-led economic interventions, tackling unemployment and 
enabling local governments to collect increased revenues with an expanded tax base. In Uganda, therefore, LED has been institutionalised and is part and parcel of the framework of the overall development programming and implementation.

\section{Contextual perspectives}

There is an LED policy in place and all district local governments in Uganda have been directed to start LED implementation based on the experience of some districts that started LED implementation on a pilot basis. This study is based on Kasese District as a case having implemented LED with financing from the Belgian Technical Cooperation (BTC) from 2009 to 2013. Kasese District is located in Western Uganda bordering the districts of Kabarole, Bundibugyo, Kamwenge, Rubirizi and the Democratic Republic of Congo. In the 2006-2007 financial year, Kasese District with assistance of BTC embarked on the preparation for the implementation of the Kasese District Poverty Reduction Programme (KDPRP) as part of realising its development vision. The preparation began with formulation and adoption of the Kasese District Development Path Initiative (KDDPI) based on the efficient service delivery provision and LED implementation.

The KDPRP implemented in the LED framework provided Kasese District Local Government the opportunity to practise LED implementation techniques. For the period from 2009 to 2013, Kasese District implemented LED under the said programme. But there were a number of challenges and constraints that were experienced.

Firstly, there was no mechanism for how the actors, notably the local government, the civil society and the private sector, could relate to one another in the implementation process. Related to this, the CSOs and the private sector actors are imbued with a mindset to think that government is to fund everything (KDPRP Report 2009-2013) (Renno, Twinamasiko \& Mugisa, 2012). Additionally, there are no clear role differentiations, and therefore the contribution of the sectors other than the local government remained unclear. Even the capacity to handle implementation of the project and programmes in 'public-private partnership' framework is glaringly lacking (KDPRP Report 2009-2013).

As a result of that, issues and functions such as resource mobilisation for locality development and participatory and collaborative impact assessment could not be handled for improved LED implementation. Institutionalising sustainability of the programme outcomes and the impact of the LED process became difficult to come by. The technical, political, civil society and the private sector are key in the implementation of the LED programme. The technical sector has been instrumental in planning and implementation of development programmes, mobilisation and collection of local financial resources and ensuring technical support for local government functionality and technical support in local government functionality and operationalisation. The political sector has strengthened local leadership systems, balancing local politics for development, mobilisation of the masses for local development and playing the oversight role (KDPRP Report 2009-2013).

Civil society has interceded between citizens and the state, organised the masses into viable groupings, supported the citizens in nation building, supported local development through advocacy and funded interventions that supplement government programmes. The private sector has provided microfinance credit services, job and employment creation, productivity through competitiveness and innovation and financial sector promotion (KDPRP Report 2009-2013).

\section{The problem statement}

Local governments are expected to enhance LED to ignite development in their local jurisdictions. Indeed in the Ugandan context, LED is being used as one of the major avenues to improve the livelihood of the local populace. In spite of the existence of LED implementation framework plus the legal and technical mandate to cause local development, many local governments in Uganda are still not able to make considerable improvement in the overall livelihood of the people. For example, in the Kasese District, poverty levels are still high, unemployment persists undeterred and income disparities are widening (KDPRP Report 2009-2013).

Despite the abundant natural resources, the district has not been able to mobilise and utilise the existing potential for causing development for its people. One would have expected the district to have registered some impact on the poverty situation considering that poverty reduction programmes that were implemented in the district for a good number of years; however, this is not the case. The problem is that although the district has an LED institutional framework, its promotion and implementation are still a challenge. Consequently, this creates implementation gaps in terms of quality management of the LED process, availability of leverages on sharing of information on skills and finance process, infrastructural development, quality social services, accessibility to the financial services, quality agricultural extension services, developed collaborative network governance and monitoring and evaluation (M\&E) for good governance in the districts. Therefore, this study investigated the effect of institutional roles in implementing LED in Uganda, taking a case of Kasese District Local Government.

\section{Theoretical framework}

This study was guided by three suitable theories, viz. the Neoliberal Theory, the Endogenous Growth Theory and the Empowerment Theory. The three are basically inclined to the key variables of the study, helped to underpin the study and were of use in discussing the findings in section four. The Empowerment Theory was adopted as the lead theory in this particular study. 


\section{Empowerment theory}

The Empowerment Theory developed by Julian Rappaport, Oakley, Clayton and others provides that empowerment is associated with enabling people to participate in their own development. Since the 1980s, empowerment has become central to the work of many development organisations in the developing world. In contemporary development discourse and the current academic debates on poverty alleviation, empowerment is associated with enabling people to participate in their own development. At the core of the concept of empowerment is the idea of power. By power, we mean the ability or capability for people to manage and gain control over their lives either by themselves or with the help of others. According to the World Bank (2002), 'empowerment is the process of enhancing the capacity of individuals or groups of individuals to make choices and transform these choices into desired actions and outcomes'. SDC (2004) conceptualises empowerment as:

an emancipation process in which the disadvantaged have their capacity enhanced to exercise their rights, obtain access to resources, and participate actively in the process of shaping society and making decisions. (p. 9)

The Empowerment Theory provides the theoretical arguments explaining the causes of underdevelopment and poverty (Neil 2001). Empowerment theorists argue that underdevelopment and poverty persist because rural people are powerless and lack the capacity and capability to make choices that lead to the transformation of their lives. Empowerment is the process of obtaining basic opportunities and capabilities for the marginalised and poor people. Empowerment also includes encouraging and developing the skills of the local people for self-sufficiency. From the 1980s onwards, governments of the developing countries have adopted development strategies that can ignite development from below, a development approach that is community driven, targeting resources at the community level and aimed at accelerating development with the participation of the local people. The whole idea is a local development strategy that is focused on strengthening decentralised institutional arrangements for empowerment, governance, service provision and private sector growth for sustainable capacity for local development (Helling, Serrano \& Warren 2005).

Empowerment in this context means people and communities having both the opportunity and the capability to participate effectively in social, economic and political activities for their own development. Empowerment Theory lays much emphasis on participation, capacity building, economic improvement, democracy and transparency, which are the key tenets of LED. In the context of local development as an approach, empowerment is central to local development; ipso facto empowerment is the starting point of the LED process (Helling et al. 2005). Through empowerment, members of the community should have the opportunity the availability of strategic options; members of the community should also have the capability - the ability to make meaningful choices and be able to express themselves on those choices through institutions that enable them to voice their concerns on the socioeconomic well-being. Once such a situation is obtained at the local level, then the community is said to have been empowered at the locality. With this in perspective, it can clearly be deduced that the Empowerment Theory is part and parcel of the body of theoretical work that is underpinning LED.

In relation to this study, in contemporary development discourse and the current academic debates on poverty alleviation, empowerment is associated with enabling people to participate in their own development. Through empowerment, members of the community get the opportunity to make meaningful choices and be able to express themselves on those choices through institutions that enable them to voice their concerns on the socioeconomic well-being.

\section{Neoliberal theory}

The Neoliberal Theory advanced by scholars including David Harvey, Milton Friedman and Frederick von Hayek is based on the philosophy of free market mechanisms and a global market structure as a tool for economic growth leading to poverty alleviation. The Neoliberal ideology assumes that welfare states should be abolished. It further asserts that free markets, free trade and the unrestricted flow of capital will produce best results in the political and economic spheres for the good of society in general. Neoliberals assume that in a free market economy, the market will liberate private enterprises from any government restrictions and allow freedom of capital to flow and create conditions of competitiveness leading to profit maximisation. Through such self-regulated market systems, there will be a 'trickledown' in wealth distribution extending to the local people at the lower levels of society. Another perspective of Neoliberalism is by Nathan (2008), which assumes two perspectives or dimensions. He postulates that with the liberation of economic geographies, spaces of resource production in order to gain efficiencies are deemed crucial to global market competitiveness. The second assumption of Neoliberal reform is the one that involves policies that encourage place-based actors to achieve a measure of independence from corporate resource production, to act self-sufficiently and to mobilise local entrepreneurialism as a means of directly participating in bigger and broader economies.

Neoliberalism assumes that market dynamics should freely operate considering that this will contribute to socioeconomic development. It is also worthwhile to note that a neoliberal approach facilitates the adoption of entrepreneurial values of competitiveness and decentralisation, which is the bedrock of a pro-poor LED support initiative as it will open up opportunities for locals to participate actively in economic activities for poverty alleviation in a liberalised economic dispensation (Nathan 2008). 
In relation to this study, LED programmes should be duly supported. This theory will be used to support the initiative as it will open up opportunities for locals to participate actively in economic activities for poverty alleviation in a liberalised economy. It is important to mobilise local entrepreneurialism as a means of directly participating in bigger and broader economies

\section{Endogenous growth theory}

Endogenous Growth Theory by Paul Romer and Kenneth Arrow is an economic theory, which holds that economic growth is as a result of endogenous factors. The theory holds that investment in human capital, innovation and knowledge are significant contributors to economic growth. The idea of endogenous growth took root in the 1980s as part of the response to the exogenous theory, which argues that economic growth is an outcome of external factors. Proponents of the exogenous growth approach assumed that increased productivity relies on external technological knowhow. But the endogenous growth theorists have countered this by arguing that economic growth in the developed and industrialised countries was cultivated and sustained from within their countries. The theory has relevance to LED considering that the word 'local' or the concept of 'local' refers to the process of valuing the endogenous potentials and making use of the already existing local capacities (Oduro-Ofori 2011). It is also worthwhile to note that the endogenous development approach is an approach to socioeconomic development focusing on localities and their existing resources. The endogenous development approach emphasises the internal potentials of an area (Oduro-Ofori 2011). Endogenous development is 'development from within' and is based on regional decentralisation and is characterised by self-reliance and sustainability (Sakamato 2003). Endogenous development as an approach is characterised by territory, is local in orientation and relies on endogenous potentials - the development process is based on local resources; participation involving local institutions and actors in development is another characteristic of endogenous development.

While the endogenous development approach does not have a significant and comprehensive theoretical foundation, it is related and based on the ideas that have roots in the Endogenous Growth Theory (White \& Gasser 2001). It is a naked fact that the principles of the Endogenous Growth Theory are the foundations on which endogenous development is based and the LED process fits within the framework of endogenous development. This is attested to when we consider the four pillars of LED promotion put forward by White and Gasser (2001). The four pillars include participation and social dialogue among local actors, the territorial aspect based on location, mobilisation of local resources and local ownership of the process.

Considering that LED focuses on a local area's potential and its existing resources, identification of local stakeholder's need and what they can do to ensure that their local area reaches its potential to ignite a development process, the LED is underpinned theoretically on the endogenous growth paradigm of development.

In relation to this study, participation and social dialogue among local actors, the territorial aspect based on location, mobilisation of local resources and local ownership of the process are very important when it comes to LED implementation. On the other hand, LED in developed and industrialised countries has been cultivated and sustained from within their countries and so developing nations should follow suit.

\section{The conceptual framework}

The key concepts in the study were institutional roles and implementation of LED.

According to Blakely (1994), LED refers to a process by which local governments and community-based groups manage their existing resources and enter into new partnership arrangements with the private sector or with each other to create new jobs and stimulate economic activity in a welldefined economic zone. It is the process by which the public, business and nongovernmental sectors partner to create better conditions for economic growth and employment generation with the aim of improving the quality of life for all (World Bank 2000)

Government of Uganda LED Policy (2014) defines LED as a process through which local governments, the private sector and communities form partnerships to mobilise, manage and invest resources effectively into economic ventures to stimulate development and growth of the locality (Binswanger-Mkhize, De Regt, \& Spector 2010). Trousdale (2003) has the view that LED is a participatory process, in which local people from all sectors work together to stimulate local commercial activities resulting in a resilient and sustainable economy. The term 'local' in the concept refers to the process of valuing the endogenous potentials and making optimal use of already existing local capacities.

The term 'economic' is directed towards the identification of investment opportunities supporting entrepreneurial activities and facilitating access to new markets. The term 'development' is used here to refer to the process aimed at promoting an improvement in the living and working conditions of the local area through the creation of new jobs, the retention of existing jobs and the generation of income. In this study, LED is viewed as a process in which the partnerships between the local government, the private sector and the community being represented by civil society groups stimulate and encourage activities of the economy that have a bearing on economic outcomes through the utilisation of resources of a well-defined territory.

A local government is an administrative body of a small geographical area such as a city, town, county or state. Local governments can elect officials, enact taxes and do so many 
other things that a national government would do on a small scale. A local government is defined as a government of a specific local area constituting a subdivision of a major political unit as a nation or state. Oduro-Ofori (2011) refers to it asall subnational units of government below the central government legal personality having specified powers to perform certain specific functions, involving citizen participation and having substantial and staffing autonomy in the promotion of development of its area of jurisdiction. However, in this study, a local government was understood to mean a subnational government with devolved political, administrative and fiscal authority, powers, functions and responsibilities to steer service delivery provision with a full mandate to champion local development strategies for the socioeconomic well-being of the local people.

An institution is a structure of social order governing the behaviour of two or more individuals identified with (1) a social purpose and permanence transcending individual human lives and intentions and (2) the making and enforcing of rules governing cooperative human behaviour. Actually, an organisation is an institution made up of a group of people who work to achieve one or more shared goals.

Local economic governance is about strengthening the governance capacity of local institutions to manage economic growth and other development challenges at the local level taking advantage of the opportunities of economic liberalism ushered in by the globalisation dispensation (Tolentino 2011). Local economic governance is about formal and informal institutions at the local level, which evolve and are strengthened through partnering to underpin economic activities. Through partnerships and networks, local governments coordinate with other actors and institutions to address the problems of economic growth and strive to create governance systems to manage the development process at the local level. It must be emphasised that the partnerships, collaborations and networks coalescing at the local level and their enhanced participation in governance issues help to devise and implement commonly agreed measures to improve the locality by stimulating economic growth and enterprise development.

For the purposes of this study, technical roles refer to planning management, implementation of development programmes, mobilisation and collection of local financial resources, technical support for LG functionality and technical support in local government functionality and operationalisation.

Political roles were looked at in terms of strengthening local leadership systems, balancing local politics for development, mobilisation of the masses for local development and oversight role. Civil society roles were looked at in terms of interceding between citizens and the state, organising the masses into viable groupings, supporting the citizens in nation building, supporting local development through advocacy and funding interventions that supplement government programmes.
Private sector roles refer to provision of microfinance credit services, job and employment creation, productivity through competitiveness and innovation and financial sector promotion. Implementation of LED process was measured in terms of quality management of the LED, availability of leverages on sharing of information on skills and finance process, infrastructural development, quality social services, accessibility to the financial services, quality agricultural extension services, developed collaborative network governance and M\&E for good governance.

\section{Methodology}

A descriptive cross-sectional survey design was adopted for the current study as it is intended to permit an in-depth study of fundamental themes. The descriptive cross-sectional survey designs validate emerging constructs and proposition in the data set, guiding the study of various units within the identified case by underlining the mechanism by which an incident is brought to being (Kothari 2004). The quantitative and qualitative approaches were adopted in sampling, collection of data, data quality control and data analysis. Triangulation was adopted for purposes of getting quality data. Triangulation means using more than one method to collect data on the same topic (Somekh \& Lewin 2005). The study was based on a sample size of 120 that was drawn from a population of 152 . The sample size of 120 was thought to be sufficient in that where a total population is 152 , a sample size of 120 and above is sufficient.

\section{Findings and discussion \\ Technical roles and the implementation of Local Economic Development}

The study findings revealed that technical roles influence the implementation of LED in local governments of Uganda. The results show that the correlation coefficient is 0.444 and its significance level 0.000 . This implied that technical roles influence the implementation of LED in the Kasese District. Regression was further done to determine the strength of the relationship between technical roles and the implementation of LED. The coefficient of determination (Adjusted R square) value is 0.441 ; this implied that technical roles explained only $44.1 \%$ of the implementation of LED. Therefore, according to the results, there is a positive significant relationship between technical roles and the implementation of LED. Findings revealed that there is a positive significant relationship between technical roles and the implementation of LED.

Whereas organisations and technical capacity are key to effective implementation of development programmes at the local level, there must be deliberate mechanism of enhancing the availability of technical staff and how their capacity can be increased and sustained (Edralin 1996). But according to the findings, the organisational and technical capacity in Kasese District is still inadequate. With regard to the enabling environment in terms of the legal and institutional framework, the situation in Kasese according to the findings is that there is no law empowering the local government to 
partner and hold the key actors and stakeholders together with their key roles defined. Even the national LED policy is still being implemented by the central government without due regard to the peculiarities of localities. On the issues of the institutional structure and organisational setup, this is a key factor to the creation of LED operationalisation systems and mechanism (John 2012). However, in Uganda and indeed Kasese as a district, the organisational and institutional setup is not yet tailored towards LED implementation. As far as planning is concerned, Rogerson (2003) asserts that data for planning are essential for local governments to effectively plan for their own development. Actually, successful LED implantation is a function of good data collection and management for local development. However, in Kasese, this is an area where the district is still weak.

It was established that Kasese District still has inadequate sources of finance to support LED implementation. BTC was the sole funder and pulled out and so sustainability remains a problem. The financial capacity must be in the mind of all stakeholders as to whether the local government is able to marshal available opportunities to mobilise resources for economic development (Gardener 2012).

\section{Political roles and the implementation of Local Economic Development}

The study findings revealed that political roles have an influence on the implementation of LED. The results show that the correlation coefficient is 0.171 and its significance level 0.009 . The coefficient of determination (Adjusted $R$ square) value is 0.445 ; this implied that political roles explained only $44.5 \%$ of the implementation of LED. Therefore, according to the results, there is a positive significant relationship between political roles and the implementation of LED.

Political leaders at the local government level represent the people and their interest and therefore have a significant role in LED implementation. The roles of local politicians in local government and local development in particular are varied. It was established that in Kasese, the leaders participate in the management and allocation of natural resources for sustainable development given the political influence they hold. This finding is in line with CoGTA (2003) and Hall et al. (n.d.) who submitted that political leaders play a role of strengthening local leadership systems and balancing the local politics to enhance stability for development. That being the case, political leaders mobilise the local masses to participate in the local development and implementation process by championing resource mobilisation and revenue enhancement efforts for development. Local politicians have a role to play in coordinating priority setting for planning, formulating and approval of local development plans.

Findings revealed that there is no clearly spelled out legal framework for the implementation of LED. John (2012) notes that the decentralised governance framework in Uganda bestows to the local governments the planning, legislative and fiscal powers. In fact, the legal framework exists, except that there are challenges of unequal fiscal relationship between the central and local governments. A case in point is where the governance framework in place devolves significant functions and responsibilities but with minimum discretion, hence rendering the local government unable to perform optimally.

The public-private partnership arrangement in Kasese is yet to take off. The partnership arrangement with non-state actors for LED implementation can only again be sanctioned from the centre because local governments do not have the required jurisdiction to make the necessary legislation that can bring together the state and the non-state actors at the local level. Situations of this nature impair the effectiveness of the local councils to set the scene for LED implementation (Kasumba 2013).

\section{Civil society roles and the implementation of Local Economic Development}

The study findings suggest that civil society roles influence the implementation of LED in the local governments of Uganda. The results show that the correlation coefficient is 0.366 and its significance level 0.000 . The coefficient of determination (Adjusted $\mathrm{R}$ square) value is 0.338 ; this implied that civil society roles explained only $33.8 \%$ of the implementation of LED. Findings revealed that there is a positive relationship between civil society roles and the implementation of LED.

The same findings were echoed by Ghaus-Pasha (2004), who observed that implementation of many socioeconomic programmes in developing countries have always been done in partnership with the CSOs. CSOs have been involved in rural electrification, solar power generation, irrigation schemes and agricultural modernisation. Accordingly, World Bank (2012) put it that CSOs§ being multifarious and ranging from community and indigenous groups through faithbased and charitable organisations to nongovernmental organisations, labour unions, professional associations and foundations easily support the implementation of local development policies. There is considerable upsurge of interest throughout the world in the CSOs, which are now recognised as important actors in the development process (Ghaus-Pasha 2004).

The finding is also in line with Mutabwire (2012), who notes that looking at the perspectives of development and its paradigms, CSOs are vehicles for national and local policy implementation as they perform delegated functions from central government and also champion the provision of services to the local population.

Accordingly, even Oduro-Ofori (2011) believes that CSOs are resourceful and innovative in the implementation of development programmes. It is also submitted that CSOs make an enormous contribution to human development, filling the gaps between the government, the business sector and the family and consequently influence local policy implementation. 


\section{Private sector roles and the implementation of Local Economic Development}

The findings of the study revealed that private sector roles influence the implementation of LED. Therefore, this implies that there is a positive significant relationship between private sector roles and the implementation of LED. The results show that the correlation coefficient is 0.478 and its significance level 0.009 . The coefficient of determination (Adjusted R square) value is 0.355 ; this implied that private sector roles explained only $35.5 \%$ of the implementation of LED.

Relatedly, Krishna (2011) notes that the world over, the private sector is the major contributor and an engine of economic growth and development. Promoting a more dynamic and vibrant private sector, a country will have a place in renewed efforts to reduce poverty and stimulate economic growth and development. The private sector has been involved in a number of activities with the local government in relation to LED.

It was established that the private sector has stimulated and strengthened local development; hence, this has been done through provision of incentives for entrepreneurship and investment because these two contribute to growth by increasing the productive capacity of the economy, and then creating jobs and introducing technology. The private sector in Uganda has a number of challenges that are mostly internal and need to be sorted out before the sector becomes vibrant. Although markets have been established, the local people have been adamant to pay the market dues for the stalls in the market. The findings are consistent with Mutabwire (2012), who noted that there is an additional problem of market failures that are rampant in the economies of the third-world countries. Therefore, the challenge is how to handle those market failures to ensure that the private sector performs its role for successful LED implementation.

\section{Conclusions and implications}

Local governments should be empowered to attract and retain well-trained technical people capable of mounting strategic planning for LED implementation. A Capacity Building and Capacity Development programme on LED should be designed and implemented using the District Planning Units as the fulcrum of those activities and extending that capacity training to all other actors.

There should be a shift of emphasis - to 'migrate' from the sectoral planning to territorial- or locality-focused development planning based on the knowledge about the endowments of particular localities. That kind of shift in planning at the local level will set the stage for LED implementation involving key stakeholders. As part of implanting LED at the local level, LED should be mainstreamed in the governance and development processes.

The technical staff should form the LED resource pool that should mount mass mobilisation programmes popularising
LED as a local development strategy capable of pulling the masses out of poverty and creating development at the local level. Local governments should be assisted to create proper LED institutional setups with efficacious frameworks of participatory planning involving key actors and stakeholders for effective LED implementation.

Whereas the legal framework empowers the local politicians to champion service delivery to the population with LED being one of the areas, there is a problem of unequal fiscal relations between the central and the local governments. Therefore, the study concluded that there is a positive significant relationship between political roles and implementation of LED in local governments of Uganda. Without an empowered political leadership with the required skills and powers to work out its mandates, LED implementation will not be possible.

Therefore, therea is need for the empowerment of the local political leaders to find a way of how to engage different stakeholders in the formulation of LED strategic action planning for locality development. A governance framework with appropriate local and institutional systems should be worked out to allow the sharing of information for participatory planning, resource mobilisation and resource allocation for development.

The CSOs should declare funds allocated by donors for development so that the districts can harmonise their plans with the plans of the CSOs to avoid duplication of development efforts. This will help push LED to greater heights. Operation Wealth Creation should partner with the CSO to stimulate rural agriculture development in Kasese District.

The public-private partnership arrangement in Kasese has not yet been operationalised because it lacks the requisite legislation to become operational. The private sector in Kasese is still fragmented and hence not effective in igniting entrepreneurialism plus being an effective tool of creating economic growth at the local level. Even where the private sector participated in the LED implementation in Kasese, effective participation was inhibited by the mentality that government should do everything.

The private sector should come in and help the district in the ongoing activities and abandon the idea of thinking that everything should be done by the district local government. The area of interest where the private sector can play a significant role at the local level is one of value addition. The activities of private agencies should be regulated and this will help the district local government to follow them up and involve those agencies in the district development process. The private sector should help out in popularising the idea of LED in districts. The districts should clearly spell out the investment terms so that private investors are attracted to invest in districts. The private sector should actively participate in skills development because there are many unemployed youth in the district. 


\section{Acknowledgements Competing interests}

The authors declare that they have no financial or personal relationships that may have inappropriately influenced them in writing this article.

\section{Authors' contributions}

G.K was the project leader. G.K. conceptualised the study and did the field work. G.K.K contributed to the theoretical background and final data analysis.

\section{References}

Binswanger-Mkhize, H.P., De Regt, J.P. \& Spector, J., 2010, 'Local and community driven development moving to scale in theory and practice', World Bank, Washington, D.C.

Bitarabeho, J., 2008, 'The experience of Uganda-Local government's role as a partner in the decentralization process to strengthen local development', pape presented at the Conference on Access to Development Funding for Local Governments in Africa, Johannesburg.

Blakely, E., 1994, Planning local economic development: Theory and practice, Sage, London.

Byabashaija, D., Novembrieta, S., Nakimuli, A., Matovu, S., Manuel S., n.d. 'Benchmarking as a component of governance in Greater Bushenyi Districts, 'Benchmarking as a component of governance in Greater Bushenyi Districts,
Western Uganda', viewed 13 June 2017, from https://www.elibrary.kiu.ac.ug/ Western Uganda', viewed 13 June 2017, from https://www.elibrary.kiu
jspui/bitstream/1/6/1/BIMC9_\%20Dr.\%20Byabashaija\%20Deusdedit.pdf

Edralin, S.J. (ed.), 1996, Local governance and local economic development: Research findings on capacity-building, United Nations Centre for Regional Development, Nagoya.

Gardner, B.L., 2005. Causes of Rural Economic Development, Agricultural Economics, 32(s1), 21-41, https://doi.org/10.1111/g.0169-5150.2004.00012.x

Ghaus-Pasha, A., 2004, 'Role of civil society organizations in governance', 6th Globa Forum on Reinventing Government Towards Participatory and Transparent Governance, 24-27 May, Seoul, Republic of Korea.

CoGTA, 2003, 'White paper on traditional leadership and governance', viewed 13 June 2017, from https://www.cogta.gov.za/cgta 2016/wp-content/uploads/2016/07/ White-Paper-on-Traditional-Leadership-and-Governance.pdf

Government of Uganda LED Policy, 2014, 'Local government development planning guideline', Government of Uganda, Kampala.

Hall, D., Osland, K., Fowler, S., Mullen, K., Audet, M., Keane, K., et al., n.d., 'The power of local leadership', viewed 13 June 2017, from https://nytimesineducation.com/ spotlight/the-power-of-local-leadership

Harvey, D., 1989, 'From managerialism to entrepreneurialism: The transformation in urban governance in late capitalism. Geografiska Annaler. Series B', Human Geography 71(1), pp. 3-17.

Helling, L. Serrano, R. \& Warren, D., 2005, Linking community empowerment, decentralized governance and service delivery through a local development framework, World Bank, Washington, D.C.

John, K., 2012, Rural agricultural programmes: Towards effective economic growth in Uganda. International Food Policy Research Institute, Washington D.C.

KDPRP Report, 2009, Kasese District Poverty Reduction Program, Annual Report, Belgian Technical Cooperation, Bruxelles.

Kasumba, H., 2007, 'Urban Agriculture in Ezibeleni (Queenstown), Eastern Cape: An Assessment of the practice and its contribution to the cultivator', M.A thesis, Nelson Mandela Metropolitan University, Port Elizabeth.

Kothari, C.R., 2004, Research methodology: Methods and techniques, 2nd edn., New Age International Publishers, New Delhi.

Krishna, A., 2011, 'An integrative review of sensory marketing: Engaging the senses to affect perception, judgment and behavior', Journal of Consumer Psychology 22(3), 332-351.
Kvale, S., 1996, Inter views: An introduction to qualitative research interviewing, Sage, Thousand Oaks, CA.

Lawless, P., 1990, 'Regeneration in Sheffield: From radical intervention to partnership', in D. Judd and M. Parkinson (eds.), Leadership and urban regeneration: Cities in North America and Europe, pp. 133-151, Sage, Newbury Park.

Lawless, P. \& Ramsden, P., 1990, 'From radicalism to partnership', Cities 7, 202-210.

Ministry of Agriculture, Animal Industry and Fisheries, 2012. Agriculture for Food and Income Security: Agriculture Sector Strategy and Investment Plan, Government of Uganda, Kampala.

Mutabwire, P., 2012, Local governments assessment, Ministry of Local Government, Kampala.

Mwesige, A., 2014, Foreword, Local Economic Development Policy, Ministry of Local Government Uganda, Kampala.

Nathan, M., 2008, 'Radical, reformist, and garden-variety neoliberal: Coming to terms with urban agriculture's contradictions', viewed from https://www.academia. edu/2411963/Radical reformist and garden-variety neoliberal Coming_to terms_with_urban_agriculture_s_contradictions

Neil, E., 2001, 'Local economic development: A review and assessment of its current Status in South Africa', Urban Studies 38(7), 1003-1024.

Nkurayija, J.C., 2011, 'The impact of globalization on Africa's development: "Rwandan tourism as key to mobilize revenue and investment"', National University of Rwanda (NUR), Kigali.

Oakley, P. \& Clayton, A., 2000, The Monitoring and Evaluation of Empowerment: A Resource Document, Occasional Papers Series No. 26, Oxford University, Oxford.

Oduro-Ofori, E., 2011, 'The role of local governments in the LED promotion in Ghana', PhD thesis, Technical University of Dortmund, Dortmund.

Renno, D.C., Twinamasiko, J. \& Mugisa, C.P., 2012, 'Kasese District poverty profiling and mapping 2011-2012', viewed, 13 June 2017, from https://www.btcctb.org/ sites/default/files/kasese_district_poverty_profiling_and_mapping_-_20112012.pdf

Rogerson, C.M., 2003, 'Local economic development in Midrand, South Africa's ecocity', Urban Forum 14, 210-222.

Rogerson, C.M., 1999, 'Local initiatives for urban economic development: The case of Johannesburg', paper delivered at the International Geographical Union Commission on Urban Development and Urban Life Conference, 9-11 September, Cape Town.

Sakamoto, T., 2011., 'Humes Economic Theory', in E.S. Radcliffe (ed.), A Companion to Hume, Wiley-Blackwell, pp. 273-296, West Sussex.

Sakamoto, K., 2007, 'Endogenous development based on African moral economy', https://doi.org/10.11619/africa1964.2007.133

SDC, 2004, Towards the LED programmes in Uganda decentralised districts, SDC, Uganda.

Shawa, A., 2008, The roles of local governments in the promotion of local economic development: An evolving UNCDF approach, The International Training Centre of the ILO, Turin, Italy.

Somekh, B. \& Lewin, C. (eds.), 2005, Research methods in the social sciences, Sage, London.

Tolentino, V.B.J., 2011, 'The Asia Foundation: Strengthening local economic governance across Asia', in The Asia Foundation, innovations in strengthening local economic governance in Asia, The Asia Foundation, San Francisco.

Trousdale, W., 2003, Strategic planning for local economic development, The Manual Volume 1: Concepts and Process, United Nations Human Settlements Program (UN-HABITAT), Nairobi and EcoPlan International Inc., Vancouver.

UNDP, 1998, Capacity assessment and development, Technical Advisory Paper No. 3, viewed 1 March 2009, from http://web.magnet.undp.org/Docs/cap/CAPTECH3. htm

White, S. \& Gasser, M., 2001, Local economic development: A tool for supporting locally owned and managed development process that foster the global promotion of decent work, Job Creation Enterprise Development Programme of the ILO, Geneva.

World Bank, 2000, Local economic development: A primer. Developing and implementing local economic development strategies and action plans, viewed 10 November 2008 from http://web.worldbank.org/urban/led/

World Bank, 2012, Making services work for poor people, World Bank, Washington, D.C. 